\title{
ВИКОРИСТАННЯ СУЧАСНИХ ІНФОРМАЦІЙНИХ ТЕХНОЛОГІЙ У ПРОЦЕСІ ПІДГОТОВКИ ВЧИТЕЛІВ ТЕХНОЛОГІЙ
}

\begin{abstract}
Горбатюк Р. М., Туранов Ю. О. Використання сучасних інформаційних технологій у прочесі підготовки вчителів технологій.

У статті окреслено важливість застосування в навчальному процесі підготовки майбутніх учителів технологій сучасних інформаційних технологій. Установлено, що застосування комп'ютерних засобів надає процесу навчання більш технологічного $i$ результативного характеру. Зосереджено увагу на впровадженні в освітній процес елементів системи автоматизованого проектування.

Ключові слова: учитель технологій, професійна підготовка, інформачійні технології, освітній прочес, компетентності, комп 'ютерні засоби.

Горбатюк Р. М., Туранов Ю. А. Использование современных информационных технологий в прочессе профессиональной подготовки учителей технологии.

В статье обозначена важность применения в учебном прочессе подготовки будущих учителей технологий современных информачионных технологий. Установлено, что применение компьютерных средств делает прочесс обучения технологичнее $u$ результативнее. Сосредоточено внимание на внедрении в образовательный процесс элементов системы автоматизированного проектирования.

Ключевые слова: учитель технологий, профессиональная подготовка, информационные технологии, образовательный процесс, компетентности, компьютерные средства.

Horbatiuk R., Turanov $Y$. The using of the modern information technologies in the training of teachers of the technologies.

The article indicated the importance of training in the preparation of future teachers of technology of modern information technology. Established that the application of computer tools makes the learning process smarter and more effective. Focused attention on the implementation of the educational process elements of computer aided design.

Key words: teacher technology training, information technology, educational process, expertise, computer facilities.
\end{abstract}

Постановка проблеми. Соціально-економічні зміни в сучасному українському суспільстві висувають нові вимоги до якості підготовки фахівців, змісту їхньої педагогічної діяльності, яка впливає на формування професійних компетентностей.

Підготовка майбутніх учителів технологій у педагогічному вищому навчальному закладі - складний процес, кінцевою метою якого $\epsilon$ формування комплексу спеціальних знань, умінь і навичок, що забезпечують успішне виконання професійної діяльності. Тому актуальним завданням вищої освіти є розвиток і використання новітніх досягнень науки, техніки і технології у створенні вдосконаленого матеріально-предметного середовища в житті та діяльності кожної людини не тільки на виробництві та побуті, а й у навчанні. 
Аналіз останніх досліджень. Різні аспекти професійної підготовки майбутніх учителів технологій розглядались у працях багатьох науковців: А. Вихруща, Й. Гушулея, О. Коберника, В. Мадзігона, Л. Оршанського, В. Сидоренка, Г. Терещука, Д. Тхоржевського та інших.

Аналіз наявних підходів доводить, що питання підготовки майбутніх учителів технологій не знайшли належного відображення i вимагають додаткового вивчення. У представленому дослідженні ми розглянемо проблему підготовки майбутніх учителів технологій до професійної діяльності на основі сучасних інформаційних технологій.

Метою статті $є$ обгрунтування особливостей підготовки майбутніх учителів технологій до професійної діяльності на основі сучасних інформаційних технологій.

Виклад основного матеріалу. Основними особливостями формування кваліфікованих педагогічних кадрів є оволодіння методологією психологопедагогічної, профорієнтаційної, загальнотехнічної та спеціальної освіти. Навчальним планом і кваліфікаційною характеристикою, на кожному етапі професійної підготовки, визначено комплекс психолого-педагогічних, суспільних, загальнотехнічних і спеціальних дисциплін, що у взаємозв'язку формують професійні вміння $\mathrm{i}$ навички, розвивають творче мислення студентів, і $є$ теоретичною та практичною основою для подальшої підготовки майбутніх учителів технологій.

3 урахуванням цілей і завдань підготовки майбутніх учителів технологій у педагогічному університеті ми орієнтувалися на дидактичний комплекс, на основі якого формувалися узагальнені професійні знання і вміння.

Дидактичний комплекс містить: типовий навчальний план і програми (навчальні, робочі); навчально-методичні посібники; методичні вказівки для проведення лабораторних і практичних занять; систему методів, засобів та форм організації навчально-пізнавальної діяльності здійснення взаємозв'язку загальноосвітніх і професійно-орієнтованих дисциплін; електронні навчально-методичні комплекси, які містять лекції, алгоритми проведення лабораторно-практичних занять, тестові завдання для поточного та підсумкового контролю, завдання для індивідуальної та самостійної роботи, перелік питань для самопідготовки і самоконтролю тощо [1].

Наші дослідження визначили, що перераховані можливості дидактичного комплексу забезпечують формування вмінь інтегрувати навчальний матеріал; перенесення знань і вмінь з одного предмета на інший; усунення дублювання (повторення) деяких тем навчального матеріалу; підвищення інтересу студентів до матеріалу, що вивчається; узагальнення та систематизацію розрізнених знань, отриманих під час вивчення суміжних предметів.

У Тернопільському національному педагогічному університеті імені Володимира Гнатюка на інженерно-педагогічному факультеті втілюється такий напрям підготовки майбутніх учителів технологій, який дозволяє поряд із розкриттям загальної специфіки спеціальності, поступово конкретизувати та деталізувати знання шляхом засвоєння інформаційних 
технологій під час вивчення загальноосвітніх i професійно-орієнтованих дисциплін. Отже, предмети, що викладаються на інженерно-педагогічному факультеті, доповнюють i значно розширюють світогляд студентів у тій сфері професійної діяльності, де поєднуються педагогічні та інженернотехнічні принципи та закономірності.

Нині навчання в педагогічному вищому навчальному закладі неможливе без оволодіння навичками використання інформаційних технологій, зокрема комп'ютерних. Склалися такі умови, коли студент у стінах ВН3 має навчитися бачити можливі варіанти використання засобів комп'ютерних технологій у своїй професійній діяльності. Навчитися такому «баченню» справа складна, яка вимагає належної підготовки професорсько-викладацького складу, сучасного технічного та програмного забезпечення. У цьому напрямі передбачено вивчення низки дисциплін, що тісно пов'язані одна з одною та сформовані так, щоб допомогти студентам у навчальному процесі.

Упровадження у навчально-виховний процес сучасних інформаційних технологій 3 використанням активних форм і методів навчання (ігрові технологіі, проблемне навчання; технологія розвивального навчання; технологія програмованого навчання; комп'ютерні технології навчання; технологія модульного навчання; технологія активізації творчої діяльності суб’єктів навчання тощо) дозволяє створити інтелектуальне інформаційне середовище, яке надає освітньому процесу університету більшої інтерактивності $[2 ; 3 ; 4]$.

Інтенсивне зростання обсягів проектно-конструкторських робіт, складність побудови графічних об'єктів, підвищення якості та зменшення термінів виконання креслень й іншої технічної документації $\epsilon$ важливим завданням упровадження в навчальний процес підготовки вчителів технології елементів системи автоматизованого проектування (САПР).

Досягнення цієї мети можливо за таких умов: систематизації та вдосконалення проектування навчального і виробничого процесів на основі інформаційних технологій; підвищення якості управління процесами графічного моделювання; використання методів багатоваріантного проектування та оптимізації; створення банку даних задля підвищення ефективності побудови об’єктів і зменшення тривалості процесу на їх створення; уніфікації і стандартизації методів графічного моделювання.

Однією 3 основних складових САПР $є$ комп'ютерна графіка, яка визначається сукупністю технічних, програмних і мовних засобів зв'язку студента $з$ комп'ютерними засобами на рівні зорового сприйняття під час виконання геометричних побудов та вирішенні різних завдань. Головним завданням комп'ютерної графіки є не тільки зображення окремих об'єктів, а також їх конструювання та вибір оптимального варіанту з наперед заданими критеріями, що є неможливим у процесі використанні звичайного (ручного) моделювання. Використовуючи універсальні пакети прикладних програм (ППП) можна створювати, зберігати й обробляти моделі та їх зображення за допомогою комп'ютерної техніки. 
Розуміння наочних методів створення об'ємних тіл формує в майбутніх учителів технологій базові знання про ефективні способи моделювання, які дозволяють створювати моделі складних за формою деталей і конструкцій.

Одним із напрямів підвищення рівня ефективності навчання професійно-орієнтованих дисциплін є педагогічно вивірене використання під час підготовки студентів інформаційних технологій у поєднанні із системою психологічних і педагогічних засобів активізації навчальної діяльності. Застосування комп'ютерних засобів передбачає опанування майбутніми вчителями технологій психолого-педагогічними знаннями, навичками використання методів навчання, прикладного програмного забезпечення, тобто використання сучасних інформаційних технологій, доступ до яких забезпечує навчальний заклад. Використання комп'ютерних засобів надає можливість під час вивчення теоретичного матеріалу звернути основну увагу студентів на 3'ясування сутності досліджуваних явищ, побудову імітаційних моделей [5], інтерпретацію результатів, отриманих за допомогою комп'ютера, зекономити час на побудову графічних зображень тощо.

Сучасні тенденції проектування машин і систем свідчать про те, що для досягнення успіху майбутній вчитель технологій має однаково добре орієнтуватися у самому об'єкті, процесі, системі проектування; в апараті оброблення й аналізу вхідної і вихідної інформації про об'єкт, процес, систему, зовнішне середовище; у математичному моделюванні, тобто в постановці та формалізації завдання, яке полягає в умінні переробити технічне завдання 3 проблемно-змістового на мову математичних схем $\mathrm{i}$ моделей і далі в спеціальне програмне забезпечення; у методах пошуку оптимального рішення; у відповідному програмному забезпеченні систем автоматизованого проектування (діалогових системах, банках даних, базах знань та ін.); у вільному володінні засобами обчислювальної техніки [6].

Оскільки вивчення предметної галузі майбутніми вчителями технологій формує в них практичні компетентності, то відбувається певне виконання студентами ролі інженера. Це дозволяє не тільки значно інтенсифікувати навчальний процес, а й підвищити теоретичний рівень і практичну значущість результатів навчання у педагогічному університеті. Крім цього, одержання знань із предметної галузі методами інженерії є не тільки ефективним, а й має на меті їх використання для одержання професійних знань підготовки фахівців технологій у різних проблемних галузях.

Згідно 3 чинними навчальними планами напряму підготовки «Технологічна освіта», передбачено вивчення курсу «Комп'ютерна графіка». Цей предмет передбачає ознайомлення студентів 3 графічним редактором КОМПАС (КОМП'ютерні Автоматизовані Системи).

Вивчення дисципліни грунтується на знаннях шкільних курсів математики, трудового навчання i креслення, що сприяє успішному засвоєнню професійно-орієнтованих дисциплін навчальних планів інженерно-педагогічного факультету. Це має виняткове значення в 
підготовці майбутніх учителів технологій до практичної роботи в школі та самоосвіти.

На рис. 1 подано модель підготовки майбутніх учителів технологій на основі сучасних інформаційних технологій.

Суттєвим чинником розроблення моделі $€$ врахування чінних нормативних документів щодо технологічної освіти. Це забезпечує добір і структурування змісту навчального матеріалу фахової підготовки вчителя технологій, проектування модульних програм загальноосвітніх і професійноорієнтованих дисциплін відповідно до навчальних планів усіх освітньокваліфікаційних рівнів і розроблення методичного супроводу.

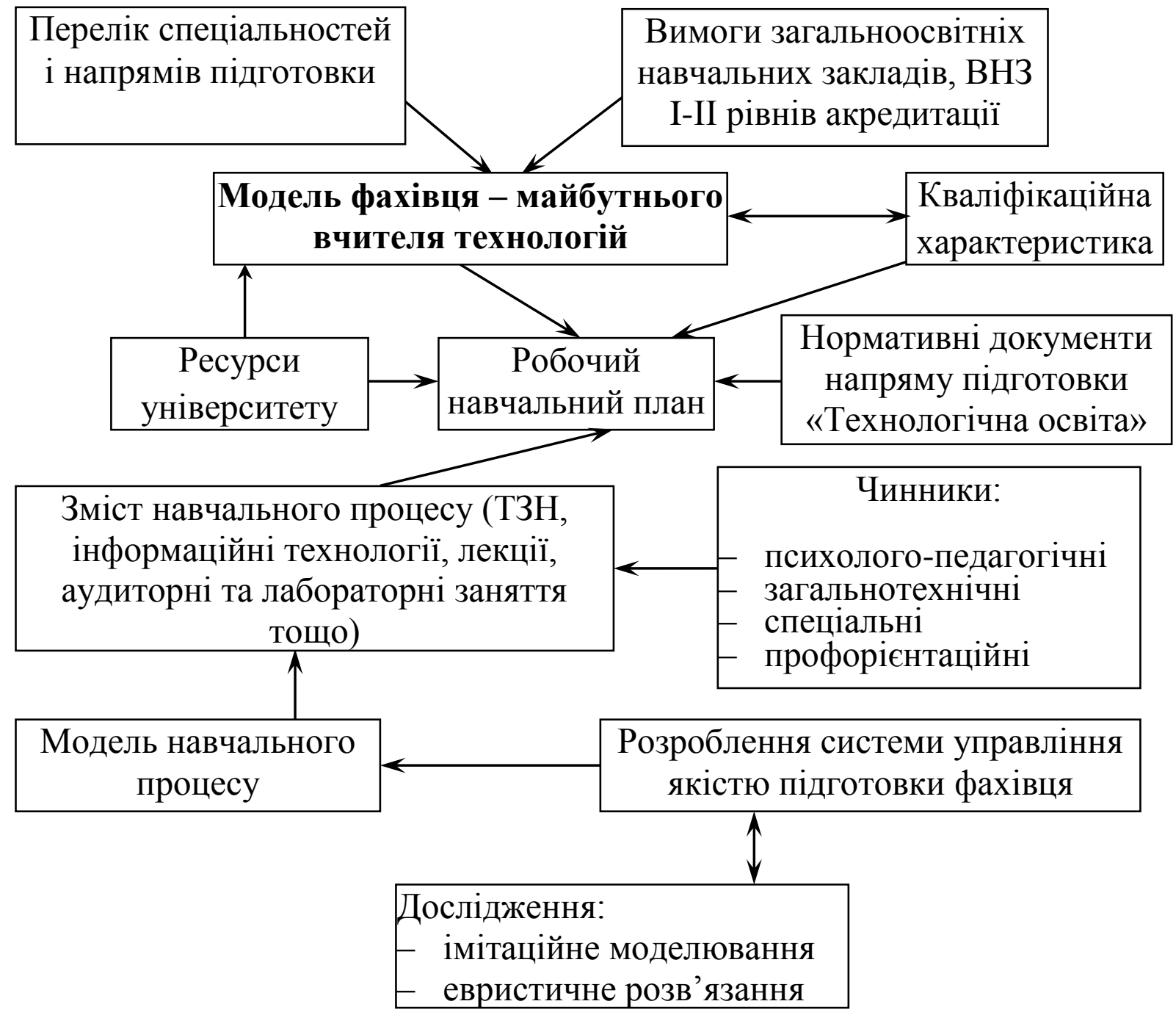

Рис. 1. Модель підготовки майбутніх учителів технологій до професійної діяльності

Вагоме значення у становленні професіоналізму студентів мають дисципліни, які забезпечують формування професійних компетентностей студентів, зокрема інформаційних. Тому навчальні плани підготовки майбутніх учителів технологій передбачають вивчення низки предметів, спрямованих 
на забезпечення їхньої інформаційної готовності, а саме: «Освітні технології навчання», «ТЗН», «Комп’ютерна графіка», «СІТ в трудовому навчанні», «Комп’ютерні інформаційні технології в освіті, науці» тощо.

3 огляду на це, у педагогічній професійній діяльності майбутніх учителів технологій комп'ютерні засоби використовуються як інструмент здійснення проектувальної, технологічної, організаційно-управлінської та науково-дослідної діяльності, а також як засіб навчання.

Незважаючи на значні досягнення в цьому напрямі, комп'ютерна підготовка студентів потребує докорінного перегляду, виходячи із сучасних вимог освіти. Передовсім, студенти повинні одержати знання комп'ютерної грамотності на рівні користувачів персональних комп'ютерів (ПК). Програма навчання має бути обов'язковою для всіх студентів, починатися 3 першого курсу і включати вивчення будови комп'ютера, операційних систем i оболонок (Norton Comander, Windows тощо). Подальше формування комп'ютерної грамотності повинно передбачати застосування у навчальному процесі підготовки майбутніх учителів технологій прикладних навчальних програм різного спрямування.

Підготовка майбутніх учителів технологій з уведенням інформаційних технологій не має обмежуватися вивченням тільки однієї конкретної дисципліни. Так, у процесі вивчення таких предметів, як «Технічна механіка», «Деталі машин», «Автоматизоване проектування в машинобудуванні» тощо, можна використовувати пакет програмного забезпечення WinMachine, редактор для математичних розрахунків MathCAD, середовище візуального моделювання MathLAB, які дозволяють одночасно описувати обчислювальний алгоритм у загальноприйнятих математичних виразах (обчислювати лінійні, квадратні рівняння, системи рівнянь, обчислювати інтеграли, матриці, знаходити похідні, будувати дво- і тривимірні графіки залежностей тощо) і тут же одержувати результати лабораторних обчислень.

Поєднуючи пакети прикладного навчального програмного забезпечення, можна створити в студентів цілісне уявлення про можливості комп'ютера, як засобу автоматизації навчального процесу. Студенти повинні використовувати ПК не тільки в навчальному процесі, а також у науковій діяльності - для написання курсових, магістерських і дипломних робіт та ін.

Застосування комп'ютерних засобів підвищує пізнавальний інтерес майбутніх фахівців до навчального матеріалу, розширює можливості цілеспрямованого впорядкованого формування, поглиблення та розширення теоретичних знань студентів, робить процес навчання технологічнішим i результативнішим. Застосування комп'ютерних технологій у навчальному процесі надає можливість систематично розглядати різні способи побудови моделей, виробничих і технологічних процесів, збільшити їх кількість, урізноманітнити зміст, розширити можливості узагальнення комп'ютерних понять. Зазначимо, що використання прикладного програмного забезпечення дозволяє викладачу значною мірою реалізувати такі загальнодидактичні принципи 
навчання, як: свідоме виконання навчальних завдань, наочність, доступність, послідовність, диференціацію та індивідуалізацію навчального процесу.

Ми переконані, що незалежно від конкретної структури комп’ютерних дисциплін на різних рівнях їх вивчення (ПТУ, ВПУ, коледж, вища школа тощо), необхідно забезпечити наступність засвоєння майбутніми фахівцями основних ідей сучасних САПР на щораз складнішому навчальному матеріалі. Передовсім це ідеї елементарності, принципи збереження, симетрії. Посилення тенденцій до інтеграції в сучасному суспільстві висуває на чільне місце ідею єдності наукової картини світу, де комп'ютерні компетентності відіграють провідну роль.

3 огляду на це використання інформаційних технологій у навчальному процесі надає можливість педагогу під час занять акцентувати увагу на стимулюванні процесів саморозвитку, самореалізації й самоосвіти студентів. Ефективність заняття підвищується за рахунок того, що всі вони (студенти) повністю залучені до роботи. А цього можна досягти лише за умови розумного використання комп'ютерних засобів.

Висновки та перспективи подальших досліджень. На грунті аналізу програм, кваліфікаційних характеристик, навчальних планів і поданої моделі підготовки вчителя технологій уважаємо, що наявна система навчання потребує докорінного перегляду. Такі зміни повинні бути спрямовані на досягнення однієї мети - підготувати інтелектуального фахівця, який відповідає сучасним вимогам. Тому якість підготовки кваліфікованих учителів технологій є тією передумовою, яка має суттєвий вплив на подальший розвиток народної освіти в державі.

Перспективами подальших розвідок є розроблення системи підготовки майбутніх учителів технологій до професійної діяльності з урахуванням сучасних тенденцій розвитку суспільства.

\section{Література}

1. Горбатюк Р. М. Проблеми автоматизації освітнього процесу / Р. М. Горбатюк // Проблеми педагогічних технологій : зб. наук. праць Волинського держ. ун-ту ім. Лесі Українки. - Луцьк, 2006. - Вип. 2-4 (31-33). - С. 356-362.

2. Горбатюк Р. М. Формування комп'ютерної культури в майбутніх інженерівпедагогів на основі інтеграції психолого-педагогічної i фахової підготовки / Р. М. Горбатюк // Наукові записки Тернопільського нац. пед. ун-ту ім. В. Гнатюка. Серія: Педагогіка. - Тернопіль, 2009. - № 1. - С. 157-163.

3. Романишина Л. М. Інноваційні технології в підготовці майбутніх фахівців / Л. М. Романишина, О. Я. Романишина // Збірник наукових праць Кременецького обл. гуманітар. пед. ін.-ту ім. Т. Шевченка. Серія : Педагогічні науки. - Кременець, 2007. Вип. 2. - С. 50-57.

4. Романишина Л. М. Сучасні педагогічні технології підготовки майбутніх фахівців / Л. М. Романишина // Проблеми освіти; спец. випуск. - К. : Вид-во наук.-метод. центру вищої освіти, 2006. - С. 140-147.

5. Шеннон Г. Р. Имитационное моделирование систем - искусство и наука : [пер. с англ.] / Г. Р. Шеннон ; под ред. Е. К. Масловского. - М. : Мир, 1978. - 418 с.

6. Веселовська Г. В. Основи комп'ютерної графіки: [навч. посіб.]

Г. В. Веселовська. - К. : Центр навч. літ-ри, 2004. - 392 с.

Стаття надійшла до редакції 20.05.2012 p. 